\title{
The Constituent Assembly
}

\author{
Challenges to Liberalism
}

\section{BOLIVIA'S “CULTURAL DEMOCRATIC REVOLUTION"}

In April 2008, Bolivia's President Evo Morales was invited to address the Permanent Forum for Indigenous Affairs at the United Nations in New York. Addressing a group of nearly three thousand delegates on the first anniversary of the Declaration of the Rights of Indigenous People, Morales made a provocative recommendation. He said that the international community should "eradicate capitalism" and replace it with "communitarian socialism" if it ever hoped to save the planet from dangers like climate change. He blamed the capitalist system for fomenting industrialization and consumption based on profit and the exploitation of natural resources. He ended by offering a new set of Ten Commandments for the future of the earth, inspired by Andean indigenous values. They include renouncing war, imperialism, and colonialism; considering water, energy, and education as human rights not subject to private business interests; and constructing a communitarian socialism in harmony with Mother Earth (El Deber 2008a).

Not surprisingly, Morales gained a reputation, along with Venezuela's Hugo Chávez, as a rabble-rousing socialist leading the continent to the Left. This image was reinforced when he kicked the U.S. ambassador out of Bolivia for allegedly intervening in an uprising in the lowland capital of Santa Cruz in 2008. He also ejected the U.S. Drug Enforcement Agency, which had been carrying out a longterm low-intensity war on coca production. Morales's position as the head of the cocoa growers union and his advocacy for the "millennial leaf" did not endear him to U.S. officials.

But Morales did not gain power through an armed revolution or an illegal coup. Instead, he has clearly and consistently characterized his administration in liberal 
democratic terms. He called his government a "cultural democratic revolution" and emphasized that he and his party gained power as a result of popular elections, where he gained the greatest majority in Bolivian history. This reflects a larger trend: in recent decades, social movements across Latin America traded in the Marxist-based ideologies of class warfare that motivated 1970 movements for social change for a decidedly liberal framework tied to international discourses of both human rights and indigenous rights. Social movements across the continent turned to the framework of citizenship and rights to seek recognition and resources from the state (Alvarez et al. 1998; Postero and Zamosc 2004; Speed 2008). This was made possible by a convergence of two important trends, what the Brazilian scholar Evelina Dagnino has termed a "perverse confluence" (2003: 7). On the one hand, she suggests, social movements and civil society empowered by the return to democracy demanded more meaningful participation in society. On the other, neoliberal governance passed on many of the responsibilities of governing from the state to "responsible" neoliberal citizens (see also Peck and Tickell 2002).

In the Bolivian case, as I have previously argued (Postero 2007a), in the mid 1990s, the neoliberal government instituted such a set of political reforms aimed at ending what it saw as an inefficient, conflictive corporatist form of civil society. Through the medium of "neoliberal multiculturalism," it offered a new form of citizenship based on a decentralized system of "popular participation" in municipal development decision-making. Many indigenous and poor people ended up frustrated by the failure of these political reforms to overturn the underlying racism of the country-as well as by the terrible social costs of the accompanying neoliberal economic restructuring-but they did take on the idea that liberal institutions could be transformed to meet their interests. One response was the formation of the MAS, which, after the gas war of 2003, brought Morales to power.

Since his election in 2005, Morales and his MAS party used liberal electoral politics to push forward a two-pronged agenda. First, through executive decrees and laws passed by the MAS-controlled congress, they substantially reworked the relation between the state and market, making the state once again a primary actor in economic development. I describe this effort in greater detail in chapters 4 and 5 . Secondly, and potentially more important, the MAS government implemented an experiment in direct democracy, a popularly elected Constituent Assembly (hereafter, CA) to rewrite the constitution and refound Bolivia as a decolonized, plurinational nation. In January 2009, Bolivians passed a national referendum approving the new constitution, which enacts fundamental changes in the form of the state; grants autonomy to departments and indigenous communities; recognizes indigenous cultures, languages, and customs; and institutionalizes a new land reform program.

I suggest that these two stances-a push for social justice to overcome both colonialism and neoliberalism, on the one hand, and the embrace of liberal 
political institutions (like elections, constitutional conventions, and direct public referenda) to do so, on the other hand-are the source of a profound tension within the Morales administration. In this chapter, I take a close look at some of the conflicts that his administration has produced as it tries to balance these two frameworks, pointing out some underlying tensions within liberalism itself that sometimes make it a difficult vehicle for social change. I trace indigenous challenges to liberalism at the CA, and show how, ultimately, the Morales government opted to dilute the indigenous alternative, maintaining the sovereignty of the central state. The resulting constitution does provide new resources for peoples dominated and oppressed for centuries. For instance, one indigenous community in the lowlands used the new rights established in the constitution to convert their town into an "indigenous autonomy," a form of indigenous self-government. I describe these efforts in chapter 7. However, the history of Bolivia's CA raises questions about the relation between liberal political institutions and decolonization. Can the liberal state decolonize itself from within, using these mechanisms? That is, can liberal norms such as the rule of law, which emerge from Western notions of democracy, accomplish the transformations required to overcome centuries of racialized domination? Can the liberal nation-state form accommodate the forms of self-government that are at the heart of indigenous communities' demands for decolonization?

To think through these difficult-and probably undecidable-questions, I take inspiration from Jacques Rancière, who defines politics as a process of emancipation brought about by disagreement. As described in the Introduction, Rancière distinguishes "policing," the implicit law or order that partitions out places and forms of participation and exclusion in the world, from "politics," disagreements that call attention to the exclusions it creates (Rancière 1999). The essence of politics is found in acts that "challenge the 'natural order of bodies' in the name of equality and polemically reconfigure the distribution of the sensible" (Rancière 2004: 90). Through such acts of politics, actors can "crack open the unity of the given" and "sketch a new topography of the possible," a new "distribution of capacities and incapacities" (Rancière 2004: 49). By emphasizing these disagreements, it becomes possible to see the ongoing forms of contestation that animate contemporary Bolivia as its people attempted to decolonize, develop, and refashion their nation as a plurinational indigenous state.

Rancière is helpful here because he argues that political subjects come into being by creating a "scandal" about the "miscount" upon which the existing social order is based. For centuries, indigenous and peasant peoples in Bolivia have been challenging the coordinates that excluded them from political, cultural, and economic participation. John Andrew McNeish reminds us that this insurgency is a fundamental part of Bolivian society, because of the embedded nature of prejudice and the social divisions that make a lasting pact between state and its 
indigenous and poor populations difficult (McNeish 2008: 80). Differing regimes of citizenship - from the republican period to the postrevolutionary 1950 s to the neoliberal era-distributed rights to some, but continued to leave others marginalized, as "the part with no part" (Postero 2007a). The revolution that brought Morales into power and especially the Constituent Assembly of 2006 was a critical conjuncture where the previously impossible-real meaningful citizenship for all Bolivians-seemed possible (see Arditi 2007: 88). As McNeish reminds us, this was a moment of "insurgent citizenship," to use James Holston's term (Holston 2008). Calling on a tradition of rebellion, indigenous actors decided to use the political process to go beyond protest to engage with and enter into the state, seeking new spaces for "possible alternative futures" (McNeish 2008: 80).

The existential disagreements at the CA were aimed at the question of who counts as citizens of plurinational Bolivia and what their rights should be. To understand their debates, I ask who the subjects of this historical process are and what the common project is upon which the nation was being formed. I describe the vision of the plurinational state advanced by an alliance of indigenous peoples and peasants called the Pacto de Unidad, showing the new distribution of the sensible they proposed. Then, I consider the conflicted process through which the constitution was produced. Finally, I show how the approved constitution differs from the Pacto's historic vision, reinforcing a liberal nation-state. Ultimately, I ask whether liberal institutions can be part of emancipatory politics or if they can only serve as a form of policing, reinforcing systems of inclusion and exclusion.

\section{THE CONSTITUENT ASSEMBLY}

The Constituent Assembly (CA) was not part of the MAS's original platform. It was a long-held demand of indigenous and popular organizations that reemerged as a central demand after the 2000 water war and the 2003 gas war (Tapia 2010: 143). Many Bolivians felt that during the neoliberal years, public decision-making, especially about natural resources, had been privatized, and decisions had been made by a small elite along with transnational corporations. The CA was supposed to be an effort to reverse this, to return this to "the people," through a process of "direct democracy." Morales holds out his government as "the government of social movements," but as we saw in chapter 1 , beneath his leadership, there is a deep sea of political actors pushing towards conflicting visions of a more democratic and just Bolivia.

The Aymara theorist Rafael Bautista argues that to understand the new plurinational state, one must ask about the historical contradictions that produced it (Bautista 2010a). What was the mode of its historical appearance? How was it constituted? What did it overcome? Most important, who are the historic subjects who produced this state? How did they fill the "idea" of the state with "content"? Here Bautista uses the framework of the Bolivian political scientist René Zavaleta 


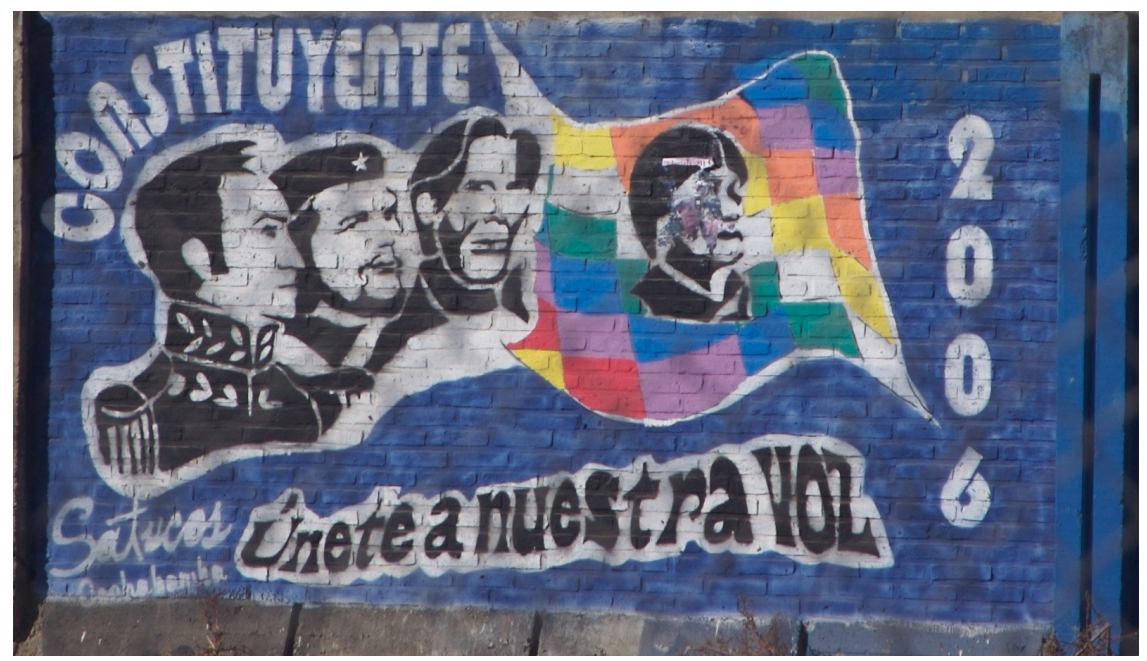

FIGURE 6. Poster for the 2006 Constituent Assembly depicting Simón Bolivar, Che Guevara, the Bolivian martyr Father Luís Espinal, and President Evo Morales (on the Wiphala flag representing Andean native peoples). Credit: A. Davey. https://creativecommons.org/licenses/by-sa/3.o.

Mercado, who argued that the previous Bolivian states were failures, only "apparent states" without sufficient "national-popular content" (Zavaleta Mercado 1986). Zavaleta uses this term to show how the demands or interests of those in the poor and Indian populations were excluded from previous forms of the state. The liberal nation-state form implies a specific relation between the state and civil society, and is based upon an assumption that the state represents the people, $e l$ pueblo, the nation. The Bolivian political theorist Luis Tapia explains that this is based on the idea of a correspondence between a "process of political unification," emerging from a set of institutions that form a single system of administration of political power, on one hand, and a "process of homogenization or unification of the culture," on the other (Tapia 2010: 151). Zavaleta argued that the Bolivian republic lacked this sort of unity because it was founded, not by the mass of indigenous peasant Bolivians, who were the "real" national popular bloc, but by the white-mestizo oligarchy, who loathed and feared the indigenous masses and always felt foreign or alienated from them. This produced the "señorial paradox" in which the elite found themselves: to kill the indio was to kill their ability to be the señor (lord or master). As a result, the señorial class never "belonged." It was never able to bring about national unity, or imbue the nation with sufficient national-popular content (Zavaleta Mercado 1986).

This paradox was not truly resolved by the 1952 revolution, when the MNR-led state included indigenous peoples by de-Indianizing them and subsuming them 
into a modernizing nationalist ideology. For Bautista, the only way the new plurinational state can overcome the still-existing colonial power relations is by finally resolving this vexing question of national unity. This real national content cannot come from the top down or from the state as an institution; rather this constituting act of remaking the state must emerge from self-conscious subjects articulating their concrete ways of life (modo-de-vida) and the rationalities of their "life worlds" (mundo-de-la-vida) (Bautista 2010a: 174). But Bautista's formulation leads to a fundamental and problematic question: how can unity emerge in such a deeply divided society? He suggests that a new, more equitable distribution is bound to emerge from revolutionary indigenous subjects who represent the "real" people. Here we return to the idea of insurgent citizens. For Rancière, however, such a guaranteed outcome is impossible and unknowable. Instead, whatever unity or emancipation might be possible can only be determined when actors challenge the established framework or police order (Rancière 2004: 90). As this chapter demonstrates, that emancipation is always uncertain.

The members of the Pacto de Unidad, the main public advocate for the plurinational state, presented themselves as historic subjects working for this emancipation. This alliance of indigenous, peasant, and workers' organizations formed in 2004 (before Morales's election), bringing together social organizations from across the country to demand a Constituent Assembly. ${ }^{1}$ The proposition that the Pacto articulated was a combination of decades-or centuries-of demands from the original peoples of Bolivia. I cannot detail here the long history of indigenous experience, memory, and claims, analyzed in great depth elsewhere. ${ }^{2}$ Let me briefly describe several important lines of "historic accumulation," emanating from the differing trajectories of the Pacto's members, that coalesced into its proposal (Tapia 2010: 136). It will have resonance with the makeup of the MAS, as described in chapter 1 , but it has some significant differences. Beginning in the 1980s and 1990s, there was a process of unification among lowland indigenous communities, marked by public marches demanding territory and cultural recognition (see Postero 2007a). In its fourth march in 2002, the lowland Confederación de Pueblos Indígenas de Bolivia (CIDOB; Confederation of Indigenous Peoples of Bolivia) demanded a Constituent Assembly, making clear the need for the state to be radically reformed to include indigenous peoples and their cultures (Romero Bonifaz 2005). Their demands for expanded notions of citizenship reflected the limitations of the neoliberal multiculturalism of the 1990s, and they left an important legacy: characterizing the people and cultures of lowland indigenous people as "nations" (Tapia 2010: 138).

The lowland project was linked to a second line, the Katarista movement of the highland Aymaras. Since the 1970s, the Kataristas had pushed for recognition of indigenous cultures, languages, and organizations from a perspective combining class and culture. They argued that indigenous peasants were doubly discriminated against, both as an exploited class and as a nation and culture (Sanjinés 2004). 
Tapia suggests that in the multicultural 1990s, Katarista activists and intellectuals were central to making Bolivians begin to recognize and accept the country's cultural diversity (Tapia 2010: 139). He argues that organizing around the idea of a nation in both the lowlands and the highlands was particularly important because it constituted critical new subjects, collectivities, and communities. "[T] he nation is a mode of translating into modern terms a process of articulation and political unification that articulates economic life, social life, social reproduction and forms of government in relation to historic territories." By considering themselves as nations, he argues, these groups positioned themselves as subjects and social totalities able to demand reform of the Bolivian state (140).

The final line of political organizing that merged with these two trajectories came from the urban popular uprisings beginning in 2000, particularly the "water war" in Cochabamba, where a wide coalition of popular movements (farmers, urban residents, factory workers, and students) united to protest neoliberal privatization of public water services (see Olivera and Lewis 2004). Popular demands included the reconstitution of public services, the nationalization of natural resources, and the establishment of a Constituent Assembly. Tapia points out that while the diverse militants of the water war did not identify as a nation, they were calling for the reconstitution of the Bolivian nation through the creation of a plurinational state. Thus the desire for a new form of the state emerged not just from indigenous people but became a "national necessity" across sectors (2010: 141).

These three trajectories converged in the Pacto de Unidad, in which members of all these groups came together to imagine and construct a new Bolivia. In the process, to use Rancière's terms, those who had had "no part" for centuries enunciated their capacity and right to a reordering of society in which they were counted and valued. This was visible at the inauguration of the CA, where indigenous groups carried signs saying “¡Nunca Más Sin Nosotros!” (Never Again without Us!). Of course the "us" in this declaration was a construction. Lowland indigenous groups and highland peasant groups had very different historical and political trajectories and had not worked together successfully in the past. So the unity of the Unity Pact was more an aspiration than a fact. Yet the historic possibilities brought them together in a thrilling political spectacle. I attended meetings of the Pacto in Sucre during the first weeks of the CA in August of 2006, and witnessed the incredible energy and hopefulness the delegates brought to the encounters. On one afternoon, hundreds of delegates, supporters, intellectuals, NGO allies, and journalists crowded into a meeting space. The leaders of the Pacto-highland peasants in their trademark leather jackets and lowland leaders in embroidered shirts-presented their proposal (detailed below), to the crowd, who responded with thundering applause. There was an overwhelming feeling that day that these were the founders of a new Bolivia, that the Bolivia they had known was from this day on going to be the past. 
On the other side of town, however, other delegates to CA had very different agendas. These were the opposition groups, who brought together a coalition of political and economic elites. The strongest sector was made up of the comites civi$\cos$ (civic committees) of the lowland departments, which represent the elite landowning and business class, which are collectively referred to as the Media Luna, or half-moon (so-named because of the shape of this region). The Oriente, or Eastern lowlands, is the main economic engine of the country, where the agribusiness elite cultivates soy, sunflowers, sorghum, and cattle for the global market. This is also the area where Bolivia's huge natural gas reserves are located. The political leaders of the Media Luna were firmly opposed to Morales's agenda of refounding the nation, and even more firmly against his efforts to overturn neoliberalism, which they saw as threatening their class interests. These elite leaders articulated their interests through a political movement demanding regional autonomy, meaning a system in which departments have the ability to tax, legislate, and make decisions about development projects, free from the oversight of La Paz. In the process, they mined long-term popular regional resentments against La Paz and racist fears (Gustafson 2006). I discuss this in greater detail in chapter 5.

The Bolivian anthropologist and MAS critic Pablo Regalsky argues that the MAS ended up in the middle, acting as an arbiter between these two sectors at the CA (Regalsky 2008, 2010). Perhaps more important to the concerns of this chapter, Tapia characterizes the Pacto as the "collective organic intellectual" that imagined and designed the new plurinational state, while the MAS acted to adapt this imaginary into the format of a modern liberal state (Tapia 2010). This statement points to the severe tensions that underlay the constituting acts of reforming the state and that continue to impact the constitution that was produced.

In an important move that stacked the decks in its favor, Morales opposed indigenous organizations' demands that they be able to send delegates to the CA representing their organizations, based on usos y costumbres (traditional norms). Instead, the MAS limited the number of indigenous delegates to the CA, and insisted on an election scheme based on political party membership. This allowed Morales to control a majority of MAS delegates and to pull indigenous representatives into the CA as their own MAS delegates. The minority opposition parties, held together by the lowland civic committees, resisted the MAS actively, boycotting Assembly meetings. In the middle of the CA, they held a referendum to create a new legal status of departmental autonomy (even though the Electoral Court ruled it illegal). It was in this context of ethnic polarization and political confusion that the Constituent Assembly took place.

\section{TROUBLING TACTICS}

The August 2006 inauguration of the CA in Sucre-where the first Bolivian constitution was written in 1825 entirely by white, landowning men-was a political 
spectacle, attended by delegations from all the country's indigenous groups and social movements. There was an incredible feeling of social revolution in the air. The MAS delegates, most of whom were indigenous or from the popular sector, occupied 52 percent of the seats, physically embodying a startling statement about the revolution at hand.

After the heady days of the inauguration, the Assembly began its work. While the MAS had a majority of delegates, it did not have the two-thirds majority necessary to approve new articles under the terms of the Bolivian constitution or the special law convoking the assembly. As a result, everyone knew the proceedings would be contentious. In September 2006, however, MAS delegates voted by majority to change the rules of debate. In the controversial Article 70, they declared the Assembly to be originaria (original) - as opposed to derivada, or derived from the previous constitution-and authorized an absolute majority to approve all decisions except the final text, which would still require a two-thirds majority ( $\mathrm{La}$ Razon 2006a). This caused a political firestorm, as people decried what looked like a blatant power grab. The right-wing Podemos party leader Jorge "Tuto" Quiroga said "the antidemocratic attitude of the MAS is leading to disaster [fracaso]" (La Razón 2006a). After months of political mudslinging, the Supreme Court ruled that while the original constitution was still in force, the Assembly was in fact derived from it and the ley convocatoria (the enabling legislation), and so the delegates to the assembly could not depart from this legal framework. MAS delegates nonetheless maintained that the assembly was something new, derived from the power of the people. "By declaring itself originaria, the Asamblea Constituyente is [now] above all constituted power, including the constitution," the MAS delegate Raúl Prada Alcoreza said. This was not a constitutional convention, but a constituent assembly, an "extraordinary political event that was born of social crisis" ( $E l$ Deber 2006).

This remarkable comment illustrates what the MAS delegates believed was at stake in the CA. For them, election to the assembly and the election of Morales to the presidency was not just an election in the liberal sense of representation. Rather, it was a revolutionary intervention-not just to occupy the old structures of power, but to fundamentally reshape them. They did not accept the liberal-and neoliberal-notion of the state as a neutral referee or night watchman. Instead, they were attempting to call the bluff on this "misrecognition," to change the very nature of the state. This brings us back to Bautista's argument that these were historic subjects constituting a new state on the basis of their substantive content. Yet Morales and his government were in a bind. They had come to power through these liberal institutions - and laid claims to legitimacy at the international level because of that, declaring that theirs had been a peaceful and democratic revolution. Yet these "reluctant liberals" keep running up against the difficult fact that liberal democratic institutions as they currently existed did not accomplish the form of justice social movement activists felt Bolivia needed. 
The assembly was paralyzed for months. Opposition groups held massive marches, boycotted the assembly, and in December of 2006 organized a series of hunger strikes across the country (see Fabricant and Postero 2013). At one point, newspapers estimated up to 1,200 people were on hunger strikes (La Razón 2006b). Finally, in February 2007, the MAS and the right-wing political parties reached a settlement, in which each article would be approved by two-thirds of the commissions in charge of it, and then by the entire body, and then pass to a public referendum for approval of the full text. (Unresolved articles would pass to a committee to be settled, or go to public vote in the referendum.) With this compromise, the assembly ended its seven-month impasse and began its work on the content of the new constitution.

The tensions that began the CA never diminished, however. Commissions assigned to tackle the difficult issues such as land reform, autonomy, and indigenous rights worked diligently, but with great divisions (see Schavelzon 2012 and Beaulieu 2008 for excellent accounts of the workings of these commissions). Many came up with compromise language for the text, but many submitted both majority and minority provisions. Near the end, stalemates over these issues threatened the viability of the whole process. Public protest in the streets of Sucre took a violent turn, when the MAS refused to allow Sucre delegates to propose that Sucre be named the capital, as it had been in the early days of the republic. Indigenous delegates faced violent and racist reactions from protestors in the streets and feared for their lives (Schavelzon 2012; see more about this in chapter 5). Vice President García Linera convened a dialogue with the opposition parties, but made little progress. Delegates from the Right began to boycott the Assembly's commissions and meetings, and the MAS delegates faced dangerous street violence in Sucre. Finally, Morales and the MAS made a political decision not to let the process run aground. They bused many of the delegates - not including those in the oppositional parties - to the nearby city of Oruro, and in a highly controversial special session, passed a version of the constitution by a two-thirds vote of those attending.

That text still needed to go before the Bolivian people, which required the legislature to pass a bill scheduling the referendum. That proved very difficult, inasmuch as the MAS did not control Congress, so for several months the new constitution was left hanging in the air. Meanwhile, in Santa Cruz, in September 2008, what looked like a regional coup began. Autonomy activists took control of state buildings, burning several down, and the new prefect/governor declared that the department was an autonomous entity with its own laws and leaders. A mass of highland indigenous supporters of the MAS headed for Santa Cruz, and many believed a showdown was inevitable (El Deber 2008b; Romero 2008a, 2008b). Then, in the northern department of Pando, a group of eleven indigenous MAS supporters were brutally massacred under the leadership of the prefecto/governor (Naciones Unidas Derechos Humanos 2009). The shock of this event turned the 
tide of public opinion, and led to negotiations between the state and leaders of the autonomy movement. In a few weeks, they had come up with a new negotiated version of the constitution, which all parties agreed to put to public vote. The MAS made substantial concessions on land reform, grandfathering in existing large landholdings, and limiting Morales's ability to hold office indefinitely. In exchange, departments won limited autonomy and ability to administer their own revenues. The referendum took place on January 25, 2009, and the constitution passed by a 60 percent margin.

I discuss the content of the new constitution below, but first I address the process by which it was passed, which was very troubling on a number of grounds. Many Bolivians expressed serious concern about the seemingly anti-democratic way in which the Constituent Assembly was run, the attempted "power grab" over the two-thirds rule, and most seriously, the way the MAS passed the constitution in Oruro. As a result, for many, this text was completely tainted. Then, the fact that the terms of the constitution, agonizingly negotiated by Assembly delegates, could be bartered by Morales and company in a political compromise seemed to make a mockery of all the claims to direct democracy. Often, these concerns were voiced in terms of the fear of an authoritarian or populist form of government. (A popular banner in Santa Cruz demonstrations declared: Evo ASESINO DE DEMOCRACIA: "Evo, Assassin of Democracy.") Many white-mestizo Bolivians characterized these actions in more ethnic terms, arguing that this was a racial takeover, motivated by revenge or reverse racism, while the majority of MASistas saw these events as absolutely appropriate actions challenging the long-entrenched power of the white-mestizo elite.

What do these tensions tell us about the possibility of balancing indigenous interests in social justice and liberal democratic notions of due process? This draws our attention to the complex relationship between populism, pluralism, and democracy, as well as the difficulties in defining or interpreting the terms themselves. In some formulations, populism is seen as external or opposed to democracy, a top-down form of government that emerges when political parties or civil society are weak or illegitimate, and inspiring leaders stand for the marginalized, excluded "people" against the immoral elite. Using a moralistic political style, populist leaders often bend the rule of law to establish an authoritarian regime that gathers power to itself while claiming to represent the sovereign will of the unitary and virtuous people (see de la Torre 1997). In the Bolivian case, this oppositional framing has been expressed as a difficult balance between popular participation and authoritarianism. Given that liberal democratic institutions have long been used by the elite to serve their own interests, some see the authoritarian use of the state to remedy this as an acceptable setting aside of democratic rules (Schilling-Vacaflor 2011). Other formulations suggest instead that populism is internal to democracy, as its redemptive face through which authentic popular will is expressed (Canovan 1999). 
Noting that populism is both constituent of democracy and also the site of violations of its norms, many scholars conclude that populism has an ambivalent relation with democracy (de la Torre 2007; Mouffe 2005). I am compelled by Benjamin Arditi's characterization of populism as the "internal periphery" or "specter" of democracy. Here he draws attention to the region where the distinction between inside and outside is both blurred and a matter of dispute (Arditi 2007: 3). For Arditi, the democratic aspect of populism and its possible ominous tones are "undecidable," and only become visible through polemic or disagreement (7). Some forms of populism are compatible with democracy, indeed necessary for it; others put it in danger. Thus, says Arditi, we can think of populism as a "symptom of democracy," a paradoxical element that can both disturb and renew democratic politics. Ultimately, he says, populism "functions as a mirror, through which democracy can look at the rougher, less palatable edges that remain veiled by the gentrifying veneer of its liberal format" (6o)

There clearly is a lot at stake: the MAS was using this liberal democratic process to operationalize its larger agenda of transforming the relation between the state, the market, and society. Market processes are surrounded by and enacted within a web of social and political relations, which act both to restrain and produce economic and industrial development. Orthodox neoliberal theorists push to disembed capital from all such constraints, arguing that capital must be allowed unfettered access and mobility (Harvey 2005: 11). Many critical of neoliberalism's caustic effects have argued that this narrow version of liberalism obscures social relations, excludes concerns about welfare, redistribution, and equity, and ultimately fails to offer a satisfying resolution of the antagonisms that are at the heart of contemporary society (see Brown 2003; Lazar 2004). This is precisely the position Morales and the MAS took. Their goal for this "radical anti-neoliberal democracy" was to embed the economy and market processes in social and cultural webs in such a way as to move towards greater equality.

The dispute over these procedures made it clear that these historic subjects did not feel bound by the constraints of existing forms of liberalism. Instead, they posed procedural and substantive challenges that drew attention to several limitations inherent in liberalism. First, liberalism's insistence on the rule of law can act as an empty formalism concerned with legal procedures over substance or justice. Laws that appear to uphold the rights of all citizens may in fact obscure-or, worse, reinforce-underlying inequalities. Citizenship is not a neutral legal status inhabited by pre-political subjects, but rather a contested process involving actors whose subject positions are not only culturally and politically constructed, but constructed in relation to the political process itself. So, who gets to be a citizen turns out to be both a procedural and a substantive question. As Rancière would suggest, then, it is by calling attention to the unequal effects of existing laws and constitutions that newly emerging political subjects enact change. So, for many 
of the delegates in Sucre, the goal of the CA was to make this historical system of injustice visible and to overturn it. Their determination to control the Constituent Assembly and to dictate the terms of the new constitution was motivated, not by a cavalier attitude to the law, but by a desire to change the law to make meaningful citizenship possible in the current contexts.

The striking signs declaring "Never Again without Us!" pointed to a second limitation indigenous delegates challenged: the fact that liberalism is based upon a Western hegemonic notion of the universal. Judith Butler has written compellingly about this, suggesting not only that the "universal" is a contested term subject to cultural variability, but also that the scope of what different peoples consider as universal is only partly articulated, and under ongoing redefinition (Butler 1996: 46-47). It is, she suggests, an "open-ended ideal that has not been adequately encoded by any given set of legal conventions" (48). Looking at it from this perspective, we might see the struggles over the CA as disputes over what rights should be considered "universal" for all Bolivian citizens. For hundreds of years, Indians were not considered legitimate bearers of any sort of "universal" right, because they were not considered fully human, rational persons, and because they did not meet the requirements to be fully participating citizens (Egan 2007). At the CA, the MAS delegates were arguing that the underlying assumptions of universality in the previous constitution were no longer valid, and would have to give way to new values and procedures. For the indigenous delegates, especially those of the Pacto, indigenous values and historic demands-not only Western ideas-formed the basis of their emancipatory politics, and they believed those ideas could radically alter the police order. I turn now to their proposal to describe how they drew together indigeneity and decolonization as an alternative to liberalism.

\section{THE PACTO PROPOSAL}

The Pacto's vision for the new plurinational state developed through dialogues and intense political debates and was expressed in two documents. After the CA was convoked in March 2006, the group that had convened in Santa Cruz in 2002 sprang into action to prepare for it. They held regional meetings across the country, which culminated in a National Assembly of Indigenous, Originary, Peasant, and Colonists Organizations in May of 2006. The result of their debates was the Propuesta para la Nueva Constitución Política del Estado (PNCPE; Proposal for the New Political State Constitution) (Pacto de Unidad 2006). This first draft lays out the idea of the new plurinational state and the reasons for it, and was intended as a tool to help orient the debates at the CA. Over the next year, as the Pacto members and advisers participated in the CA commissions and made further alliances, their proposal developed into a more polished constitution-like form, a May 2007 draft titled the Constitución Política del Estado Boliviano, Propuesta 
Consensuada del Pacto de Unidad (PCPU; Political Constitution of the Bolivian State, Consensus Proposal of the Unity Pact) (Pacto de Unidad 2007). Reading them together we can see three interlinking themes: (1) autonomy and decolonization, (2) plurality within national unity, and (3) shared decision-making.

In the first document, the authors explain the plurinational state as a "new model of the state founded by indigenous, originary, and peasant nations and peoples as a collective subject that transcends the monocultural liberal model based upon the individual citizen" (Pacto de Unidad 2006: 4). Detailing the ways the Western model marginalized and weakened pueblos originarios' (original peoples') cultures and political and judicial systems, they argue that only a model of political organization based on collective rights will "decolonize our nations and peoples" (ibid). Here we see an explicit adoption of plurinationalism over the idea of multiculturalism. As I have explained above, multiculturalism was the form of inclusion adopted by neoliberal governments across Latin America in the 1990s (Hale 2002; Postero 2007a). Recognizing the cultural diversity of Bolivia, the neoliberal state adopted laws fomenting the political participation of indigenous peoples and granting some collective rights, like collective landownership. Will Kymlicka has called this form of recognition "liberal multicultural citizenship" (1996). Yet Bolivians found that multiculturalism did not fundamentally change the underlying racism or the structure of the state. Thus, the Pacto hoped to refound the state by recognizing not just the existence of indigenous peoples, but their sovereignty as nations. ${ }^{3}$

Scholars have defined sovereignty in a number of ways. Foundational accounts characterize sovereignty as the mark of state power, evolving from the original power of the king to enact violence-the right to kill. Under liberalism, this power devolves through a social contract to "the people," understood as citizens (Hobbes [1651] 1971). Building on his definition of the political, which for him lies in the antagonistic relations between friends and enemies, the political theorist Carl Schmitt argued sovereignty was the power behind the law, that is, the power of a political entity to decide who counts as friends or enemies and what counts as law (Schmitt [1932] 1996). Recent scholarship has tried to disentangle sovereignty from state power (Blom Hansen and Stepputat 2005: 11). Foucault famously contrasted sovereign power to biopower, arguing that instead of the sovereign's right to kill, modern forms of power center on life, especially that of the population (1977). Bringing together Schmitt and Foucault, Giorgio Agamben argues that sovereign power of violence continues to be constitutive of the political community in contemporary period. Describing the sovereign sphere as a "state of exception," he showed how sovereign power can render certain people "bare life," excluded completely from legality (Agamben 1998). These theories have led Thomas Blom Hansen and Finn Stepputat (2005) to conclude that sovereignty and the violence that marks it should be studied as "practices dispersed throughout and across societies" (3). They argue 
that sovereignty is a social construction, a "tentative and unstable project whose efficacy and legitimacy depend on repeated performances of violence and a 'will to rule"' (ibid). These performances are historically and culturally specific, they say, but they always construct their authority through a "capacity for visiting violence on human bodies" (ibid). Pierre Clastres rejected such "ethnocentric" notions of political power, which he argued were based solely on Western societies. He argued that not all societies allowed political institutions or leaders to exercise such power. The "primitive" indigenous societies he studied in the Amazon region of Latin America refused to allow this potential for violence to be possessed by any one leader. Instead, in these "societies against the state," society as a whole was the site of political power, and leaders acted as mediators to promote harmony rather than to exercise command over others. Individual people and communities maintained autonomy, only giving power to leaders in emergencies like times of war (Clastres [1974] 1989).

The question of sovereignty takes on a specific valence in postcolonial settler states, of course. Robert Meister (2011) argues that in nation-states founded in the wake of settler colonialism, the claim of settlers to self-determination was at fundamental odds with the parallel claim of aboriginal peoples, resulting in the removal or elimination of those native peoples, and their erasure as peoples or nations. Thus, for most indigenous peoples, national sovereignty has always entailed their rendering as bare life. Claims of indigenous sovereignty can therefore act as a stark challenge to national sovereignty, both laying bare the violent dispossessions on which it is based, and proposing an unthinkable notion of indigenous peoples who claim membership in their own sovereign nations (Simpson 2014). Across Latin America, indigenous activists have pushed back against liberal multicultural notions of inclusion, arguing instead for self-determination and territorial control as nations.

In the Pacto's proposal, the key mechanism to accomplish this decolonized form of sovereignty is autonomía indígena originaria y campesina (AIOC; indigenous originary peasant autonomy). Seen as a path to autodeterminación (self-determination), autonomy will allow indigenous peoples to "define our communitarian politics, social, economic, political and juridical systems," and "reaffirm our structures of government, election of authorities, and administration of justice, respecting different ways of using space and territory" (Pacto de Unidad 2006: 4). This autonomy is "the condition and principle of liberty of our people and nations" and the keystone of decolonization (10).

In this description of autonomy, one can already see how it is linked to the second theme, plurality. It is because colonial structures tried to erase plurality that autonomy is necessary: to recognize and support those original peoples who resisted and still maintain their identities. But this requires a radical reform of the state. Where the liberal nation-state imagined a unified homogeneous Bolivian 
people, the proponents of the plurinational model make a very different assumption: they argue that the underlying pueblo is plural and diverse. The authors argue for plurality in several forms. First, they recognize the presence of the country's $d i$ versas naciones, pueblos, y culturas (diverse nations, peoples, and cultures) (Pacto de Unidad 2006: 4). Second, they call for juridical pluralism, defined as "the coexistence, within the plurinational state, of indigenous originary and peasant juridical systems, on a plane of equality, respect, and coordination" (4, n. 4). Third, the plurinational state should respect diverse forms of government and democracy. Thus, liberal institutions of participatory and representative democracy should co-exist with indigenous forms of communitarian democracy and mechanisms of participation such as assemblies and cabildos (mass meetings). Leaders should be elected either by universal vote or through traditional mechanisms called usos $y$ costumbres (6). These plural enactments are to be given respect, but also equal legal and political value.

These calls for and recognition of plurality are not phrased as separatism, but rather as the basis of a common and unified nation. The diverse nations and peoples have the right to convivencia solidaria y pacifica (solidary and peaceful co-existence), and to achieve this, the authors propose a "unitary plurinational state" (4). The fundamental principles of this state are "juridical pluralism, unity, complementarity, reciprocity, equality, [and] solidarity ..." (ibid). Throughout the proposals, the authors link plurality to unity, making clear that this vision of pluralism will be the "motor of unity and social well-being for all Bolivians" (ibid). In his analysis of the Pacto's proposals, Luis Tapia emphasizes the importance of reciprocity as a way to mediate the seeming tension between the need for a common government and the need to recognize difference. This, for him, is the key to decolonization: the complementary and reciprocal recognition and inclusion of those formerly depreciated by colonialism and later global capitalism (Tapia 2010: 145).

Rafael Bautista makes a similar argument. He argues that what is exceptional about the pluri in the plurinational is not just the recognition of difference or the diversity, but the historical process by which the diverse converges into community. So, rather than being simply a "culturalist" additive, the notion of the pluri acts as a critique to the devalued form of modern liberal politics, which privatizes and reduces public decision-making to the univocal colonial state. The pluri demands a democratization of the decision-making sphere, overcoming the false opposition between the state and society, making possible a congregation of all into what he calls común-unidad (common-unity). But this unity is not a given; it emerges in the process of recognition of the Other as a subject, as a human being with dignity and rights. Based in this reciprocal recognition, the pluri makes a fundamental claim: that unity is based in community or it is nothing (Bautista 2010a: 185-87).

This, then, brings us to the third axis of the Pacto's proposals: shared decisionmaking. The authors describe a form of government in which autonomous 
indigenous originary and peasant communities govern themselves at the local level and are actively involved in the state's decision-making about national issues, where they are to "co-administer and co-manage" resources (co-administración y co-gestión). Their draft called for 70 of the 167 delegates to the Plurinational Assembly (the Congress) to be elected by indigenous originary and peasant nations and pueblos. The plan to share decision-making is especially notable in the sections on natural resource exploitation, where local peoples will "participate in the making of decisions about exploration, exploitation, industrialization, and commercialization of non-renewable resources in their territories" (Pacto de Unidad 2006: 12). They would be consulted in advance about such development, and this consultation would be vinculante, or binding. Overall, the documents call for "direct representation" of indigenous originary and peasant peoples and nations in the administration and running of the plurinational state $(4,12)$. The plurinational state, then, was envisioned as a mechanism for the plurality of the Bolivian people to participate directly in "public power" (4). In the final draft, this was expressed by saying that both sovereignty and constituent power reside in the "indigenous originary peasant nations and peoples and in the culturally diverse population of the countryside and the city," who must exercise their power directly through participation in decision-making.

\section{THE PLURINATIONAL STATE CODIFIED}

The Pacto's proposed constitution was substantially modified in the political struggles between the Pacto, the MAS, and the opposition parties, first at the CA and then in the negotiations after the CA had concluded. The reasons for these modifications are complex and the subject of continuing debates. Clearly, the MAS was forced to negotiate with the opposition parties, whose stalling techniques had made the CA almost unviable. The comites civicos (civic committees), the site of local oligarchic and agribusiness power in the lowlands, were adamant about certain issues, such as limiting land reform and privileging departmental autonomy over indigenous autonomy. MAS concessions on these issues sparked accusations that they had betrayed the revolutionary potential of the CA. Instead, say critics, the "reformist" MAS failed to confront the economic power of the Santa Cruz oligarchy and chose, instead, to support the capital-intense forms of agricultural production and natural resource extraction that bring in the majority of the country's income (J. Webber 2011, 2012; see Postero 2012). Again, we must remember that since Bolivia's economy is deeply entangled with global and regional markets, Morales may have had less choice in all this than his critics gave him credit for having.

But the modifications cannot all be blamed on the need to assuage the Right or global capital. The MAS agenda was always different from the Pacto's. As Devin Beaulieu (2008) makes clear, the MAS's goal was always state capture. That is, the 
MAS chose to use the political openings of the neoliberal period, particularly electoral politics, to gain control of the state, so as to be able to restructure the national development model and then redistribute the benefits of Bolivian patrimony to the Bolivian people. Beaulieu frames the MAS agenda in Polanyian terms, characterizing it as part of the "double movement" to complete the neoliberal promise of multiculturalism and redistribution. However, he argues, the limitations of that form of power constrained social movements' abilities to change it (Beaulieu 2008: 55). This brings us back to the central question of this chapter: the possibilities and drawbacks of a strong liberal state. The MAS chose to embrace a model of the state that it felt would give it as much power as possible to accomplish its goals, while protecting its political hegemony (Garcés 2011: 63; Schilling-Vacaflor 2011). The result is a text that is not entirely coherent (Tapia 2010: 157). It contains much of the liberatory language of the Pacto's draft, especially in those sections that recognize the precolonial existence of indigenous Bolivians. However, the state form remains fundamentally liberal and reserves the majority of the power to the central state, allowing only limited forms of autonomy and decision-making subordinated to the central state.

The preamble, already cited, and the first and third articles echo and codify the "plurality within unity" theme we saw in the Pacto proposal:

Article 1. Bolivia is constituted as a state that is unitary, based on the rule of social law, a plurinational communitarian state, free, independent, sovereign, democratic, intercultural, decentralized, and with autonomies. Bolivia is founded in plurality and in political, economic, juridical, cultural, and linguistic pluralism, within the integrating state process.

Article 3. The Bolivian nation is made up of the totality of Bolivianas and Bolivianos, the indigenous originary peasant nations and peoples, and the intercultural and Afro-Bolivian communities that as a whole constitute the Bolivian people.

Throughout the constitution, plural cultures are recognized and given value. In Article 8, the constitution makes indigenous moral principles the underlying ethical bedrock of the new state. Moreover, the notion of vivir bien or suma qamaña (living well) is held up to be the ideal form of society and forms the basis of the state's economic and welfare policies.

The second article takes up the demands for autonomy:

Article 2. Given the precolonial existence of the indigenous originary peasant nations and peoples and their ancestral dominion over their territories, their self-determination is guaranteed within the framework of the unity of the state, consisting of their right to autonomy, to self-government, to their culture, to recognition of their institutions, and to the consolidation of their territorial entities, in conformity with this Constitution and the law.

This is the place in the constitution that appears most to embody the ideas put forward by the Pacto. It gives indigenous peoples the "right" to autonomy and 
self- government and the "recognition" of their institutions, but this is a far cry from a plurinational state based on the equal co-existence of plural forms of democracy and governments. Indeed, the rest of the constitution lays out what Tapia calls a "constitutional hierarchy" (2010: 157). That is, we see many elements of a traditional liberal state model, with pretensions of universality and general validity, on the one hand, and a secondary rung of different normative systems that are recognized and allowed, but under the supervision of the dominant system, on the other. This, says Tapia, is merely the sort of multicultural recognition enacted in Bolivia in the neoliberal period (156).

The Pacto proposal imagined indigenous autonomy (AIOC) as the central form of political organization in the country, making indigenous institutions parallel to the central state. In the new constitution, and particularly as it was implemented in the later law on autonomies, however, the category of indigenous autonomy is greatly reduced, or "domesticated" as Fernando Garcés puts it (2011). First, they are not open to all forms of indigenous originary or peasant organizations, but only to those municipalities or established territories (TIOCs) with majority indigenous populations that follow constitutionally approved norms and procedures (Bolivia 2009: Art. 293). This means that many long-standing unrecognized demands for territory will not be included. The law also sets out tight bureaucratic procedures by which the proponents of an AIOC status may go about claiming that status - through a government supervised referendum, and so forth. These requirements are so strict that only eleven municipalities in the whole country were able to begin the process in the first round of applications. (Chapter 7 looks at the case of Charagua, one of the eleven, and the first to win this status.) In his in-depth analysis of the autonomy process and especially the legislation implementing it, John Cameron demonstrates how government policies and practices restrict and undermine opportunities to exercise autonomy. While the MAS officially supports the conversion to AIOCs, it has provided only minimal funding for the Autonomy process. More important, in many of the communities considering conversion, the MAS has made it known to its supporters that they will not receive government support if they push for autonomy. It is clear that the state sees indigenous control over natural resource extraction as a threat to its own power (Cameron 2013).

This brings us to the second way in which autonomy has been diminished. While the idea of the AIOC was to allow original peoples the possibility of governing themselves - libre determinación - the constitution establishes a clear hierarchy of jurisdictions, with the central state carrying out the seemingly universal work of governing the country and the people, and the AIOCs making decisions that only apply to their community and do not contradict the central state (Bolivia 2009: Art. 290). In Art. 30 of the Constitution, the section dealing with indigenous rights, this is echoed: indigenous peoples have the right to their political juridical and economic systems. Most important, the constitution eliminates the heart of 
the plurinational proposal: shared decision-making. Nowhere does it mention coadministration or co-decision-making. Instead of giving a large number of special congressional seats to indigenous representatives, the constitution delegated the decision about how to proportion seats to the Plurinational Assembly, which was to draft the Electoral Law. In 2011, over huge protests by lowland groups, the Assembly settled on a tiny number: seven special seats. Perhaps most important, in the fundamental sections on natural resource exploitation (Art. 30, 15; Art. 348ff.), the central state retains exclusive control over decision-making.

Article 349. Natural resources are the property and direct, indivisible, and inalienable dominion of the Bolivian people, and it is the state's responsibility to administer them for the collective interest.

Article 351. The state will assume control and direction over the exploration, exploitation, industrialization, transportation, and commercialization of strategic resources...

And, in place of the consulta previa vinculante, the binding consultation process envisioned by the Pacto, the new constitution only guarantees a previous and informed consultation, with no possibility of the veto power hoped for in a plurinational state co-administered by complementary others (Art. 30, 15). As we will see in chapter 5 , where I describe the controversy over the TIPNIS national park and indigenous territory, this has become a source of enormous contestation, calling into question not only the government's commitment to due process but also its claims to decolonization.

\section{THE EMANCIPATORY POTENTIAL OF DISAGREEMENT}

The struggles of the Pacto de Unidad delegates to enact their vision of a plurinational state illuminates the tensions at the heart of the new Bolivian development model, where the need to develop natural resources conflicts with the interests of the local peoples to govern themselves according to their own customs. These are made visible in the stark gap between the shared decision-making the Pacto proposed and the centralized decision-making the final constitution enabled. Despite all the inspiring language about recognizing and respecting the plurality of the Bolivian pueblo, the power to decide for the pueblo remained in the hands of the central state, demonstrating the continued colonialism of what I see as a profoundly liberal state. Finally, those inclined to characterize Morales as an anti-democratic populist leader might see in the constitutional process another example of how he consolidated state power.

The contestation over decision-making also reveals something else: the profound and continuing tensions within liberal democracy itself, which take on particular valences here as Bolivians balance liberalism with indigenous visions of 
self-governance. In every state, the notion of "the people" is a constructed one, and the state must claim to legitimately represent that people, whether it be unitary or plural. Throughout his administration, Morales has held himself out as representing the sovereign will of the people-as all presidents do. His notion of who exactly this pueblo is has, naturally, varied depending upon his audience. At some points, he characterized "the people" as both poor and indigenous; at others, he has focused on more unifying notions of Bolivians. But who counts as the people and what rights they have or should have is the fundamental "political" question always at play. In the Constituent Assembly, the Pacto put forward a new vision of how Bolivia should be ordered, with a radically different "count" of who should have a part in the nation's political, cultural, and economic order. As much as Morales identified publicly with the indigenous agenda of pluralism and evokes indigenous cosmovisión (worldview) in all his international talks, it is clear that the Pacto's call for a recount severely threatened the order policed by the MAS. Morales and the MAS have worked hard to achieve the power they have, fighting off right-wing opposition parties and leftist critiques. Moreover, the Morales regime has invested enormous energy in a new "distribution of the sensible" in which the language, epistemology, and aesthetics of indigeneity are central to state legitimacy. In the next chapter, I show one way the MAS state has done this, describing a spectacular wedding held by the Vice Ministry of Decolonization and the meanings participants make of it. Thus, we can say that the MAS regime has already carried out a recount, making "the indigenous" visible-and valorized. ${ }^{4}$ This has been one of the MAS's greatest successes, in fact, giving indigenous and peasant peoples a vastly increased sense of belonging and citizenship.

Yet the disagreements visible in the struggle at the Constituent Assembly show that the MAS's positive resignification of the category of indigenous was not a sufficiently meaningful recount for the Pacto activists. For them, the questions at hand were not merely about recognition of their indigeneity, but about what that category actually means. For the Pacto visionaries, recognition of Bolivia's pluralism involves the right of that plurality to make decisions. In essence their disagreement is a disagreement about the form democracy will take in Bolivia. Is this going to be a classic liberal state where the central state retains the power to decide such things as resource extraction (or highway placement, as we will see in chapter 5) or is this going to be an "indigenous state" where local communities have autonomy to decide such things for themselves? These are not just symbolic questions. The new constitution highlights the complex material and epistemological implications of a state that is at once indigenous and developmentalist.

Such fundamental disputes are clarified when political subjects, like the Pacto activists, draw attention to a new set of emancipatory possibilities through disagreement. Rancière notes that such acts are tenuous, precarious, and not likely to alter the status quo; rather, what they do is open the possibilities to the future. 
Benjamin Arditi suggests that the Occupy movement in the United States performed a similar function, providing a "passageway to the future" simply by drawing attention ("We are the 99\%") to the miscount (Arditi 2015). The Pacto's proposal was emancipatory precisely because it interrupted the way things were ordered or policed, and produced a "body and a capacity for enunciation not previously identifiable." This, in turn, reconfigures the field of experience (Rancière 1999: 35 ). What is this new body and capacity? It is the plural body of the pueblo boliviano, the people "of a plural composition" described in the constitution and given voice and action by these "speaking beings" (30). This is not a new category, of course, but a persistent category put forward for centuries by indigenous people, and miscounted over and over again by the dominant orders. The disagreements over the constitution-both the activists' demands and the state's response-demonstrate that the category still remained miscounted in the MAS era, despite the rhetoric of plurinationalism. Now, however, regardless of the outcome in this case, this category has taken on greater political meaning. McNeish concludes that while it did not meet all the demands of its insurgent proponents, the CA process did form a "general and irreversible acceptance of the need to accept plurality as part of the national identity" (2008: 93). That is, the plurality expressed in the constitution is not just a rhetorical abstraction in the text, but an active force made up of those historic subjects Bautista referred to who are pushing the state to continue to evolve and respond. Now the state must respond to accusations of colonialism carried out by the so-called decolonizing state. Now the state is held accountable for the gap between its discourse about the pachamama (Mother Earth) and its practices on the ground. And here, we must acknowledge an important difference between the indigenous activists I describe here and the Occupy movement: while they both call attention to the miscount, the Bolivian activists also posit a territory, subject, and history from which to "disagree." That is, these speaking beings also assert that they are citizens with rights that emerge from their history and the constitution. ${ }^{5}$

This returns us to the issue of whether the MAS is a populist regime. To what extent does Morales represent the people? Which people? The Bolivian case described here makes clear that we can only evaluate the MAS's actions as part of the undecidable tensions between popular will and equality, on the one hand, and the seemingly intractable need for the state to exercise its power to manage the country and the economy, on the other (what Canovan 1999 terms the redemptive vs. the pragmatic faces of democratic government). This points out that the dual role the MAS government plays. On the one hand, the MAS has practiced an emancipatory "politics," rewriting the constitution, instituting a policy of decolonization, and engaging in a campaign of symbolic acts intended to make visible the historic racialized miscount of Bolivia's indigenous peoples. But on the other, by taking the mantle of the liberal state, it also acts as the police order, governing through law as 
well as violence, calling into being other forms of politics. This is the hybrid nature of the Morales state.

Did the Pacto activists interrupt the MAS police order? Certainly, the MAS has enormous power, but as Foucault explains, government power is never totalizing. Rather, governing is the ability "to structure the possible field of action of others" (Foucault 1982: 221). Thus, while the MAS may structure the field, it does not completely limit the ways social movements can contest its power. Clearly, the Pacto was not able to make all the radical changes it envisioned, but it did plant seeds that may develop into a real and active plurinationalism over time. The Guaraní leaders pushing indigenous autonomy in Charagua, described in chapter 7 , are working to make this a reality. The Bolivian theorist Raúl Prada Alcoreza suggests that this transition will occur as the constitution is interpreted by legislators and put into practice. He predicts that the "pluralist episteme" inaugurated by the CA debates and the constitutional text will be developed through the transgressive practices of the plural Bolivian multitude, whose collective construction of the laws will rupture the government practices (Prada Alcoreza 2014). Both Prada and Bautista remind us of what Frantz Fanon (1963) made clear, that decolonization is a continuing constituent process carried out by actors whose subjectivities are only formed in the process of struggling for revolutionary change. In contemporary Bolivia, we are witnessing precisely that: the ongoing struggle to define who counts as el pueblo boliviano and what that means for Bolivian democracy. The plurality of answers to these ultimately undecidable questions will only be illuminated by further disagreement. 